\title{
Reversible myopathy induced by clofibrate
}

\author{
D. GELTNER \\ M.D. \\ M. CHACO \\ M.D. \\ M. SHAPIRO
M.D. \\ Department of Medicine B and Department of Physical Medicine and Rehabilitation, \\ Hadassah University Hospital, Jerusalem, Israel
}

\section{Summary}

A 49-year-old man was given clofibrate in the treatment of hypercholesterolaemia. A myopathy developed accompanied by laboratory enzyme changes and a pathological electromyographic pattern. After ceasing the medication the clinical picture of myopathy disappeared and the enzyme and EMG changes reverted to normal. The EMG changes were once again produced by a short challenge with clofibrate.

\section{Case report}

A 49-year-old male clerk was given clofibrate by his family physician 1 year after he was found to have a raised serum cholesterol of $350 \mathrm{mg} \%$ and total lipids of $1400 \mathrm{mg} \%$. Several weeks after taking 1.5 $\mathrm{g}$ /day he began to complain of weakness in his limbs and became virtually incapacitated by severe pain in his muscles after mild effort. He was unable to climb a flight of stairs without resting several times, and his hand would tire rapidly while writing. On general physical examination no abnormal signs were detected. His blood pressure was $130 / 80 \mathrm{mmHg}$ and pulse $76 / \mathrm{min}$. On detailed neurological examination, the patient was unable to perform repeated sit-ups although there was no muscle tenderness and no other neurological abnormalities. The ESR was $20 \mathrm{~mm}$ (Westergren) in the first hour. Haemoglobin was 14 g\%; leucocytes $6400 / \mathrm{mm}$ with normal differential count; blood urea nitrogen $15 \mathrm{mg} \%$; serum electrolytes were within normal limits, serum glucose was $80 \mathrm{mg} \%$; total proteins $7.3 \mathrm{~g} \%$; albumin $4.6 \mathrm{~g} \%$; plasma electrophoresis normal; uric acid $7 \mathrm{mg} \%$; bilirubin, alkaline phosphatase, glutamic-pyruvic aminotransferase, calcium and phosphorus were all within normal limits, serum cholesterol was 250 $\mathrm{mg} \%$ and triglycerides $205 \mathrm{mg} \%$. Lipoprotein electrophoresis performed after medication was stopped showed the pattern of hyperlipoproteinaemia type IV. Antinuclear factor was positive although on repeated examination $L E$ cells were not found. $T_{3}$ sephadex was normal. X-ray of chest and upper

Correspondence: Dr D. Geltner, Department of Medicine B, Hadassah University Hospital, P.O.B. 499, Jerusalem, Israel. gastrointestinal series was normal. The electrocardiogram was within normal limits. The urinary excretion of creatine was greatly increased and ranged between 400 and $2400 \mathrm{mg} / 24 \mathrm{hr}$, biopsy of the quadriceps muscle did not reveal any pathological findings. The serum aldolase level was 24 iu (normal 20) but the CPK and serum oxaloacetic aminotransferase were within normal limits, 40 iu and 20 iu respectively (upper limits: CPK, 75; SGOT, 50). Electromyography showed striking myopathic changes.

Within 2 weeks of stopping the clofibrate the symptoms disappeared and the EMG changes returned to normal. Because the serum triglycerides had risen to $805 \mathrm{mg} \% 3$ months later, the drug was again administered. After 10 days of clofibrate treatment ( $1.5 \mathrm{~g} /$ day) the patient remained symptomless, but the EMG reverted again to a pathological pattern. In addition, the serum CPK had increased from $38 \mathrm{iu}$ to $90 \mathrm{iu}$. The drug was stopped and the serum CPK and EMG patterns returned to normal.

\section{Discussion}

An acute muscular syndrome associated with the administration of clofibrate has been reported (Langer and Levy, 1968; Katsilambros et al. 1972) and a rise of serum oxaloacetic aminotransferase has been noted previously (Green and Margaretz, 1967). Other studies have shown that rise in serum enzyme levels associated with this drug is infrequent (Vester, Sabeh and Danovski, 1969; Smith, Macfie and Oliver, 1970). Electromyographic changes have not been described in association with clofibrate myopathy.

In this report a patient is described who developed weakness, malaise, stiffness and incapacitating myalgia with striking myopathic changes in the electromyogram (EMG) after taking clofibrate (Atromid-S) (ethyl $\alpha$-p-chlorphenoxyisobutyrate). This was accompanied by increased excretion of creatine in the urine and raised muscle enzyme levels in the serum. The symptoms disappeared when the drug was discontinued, but the EMG changes recurred promptly when clofibrate was administered again. After stop- 
ping clofibrate for the second time the EMG and biochemical changes disappeared once more.

This appears to be the first patient reported in which reversible EMG changes are demonstrated after repeated clofibrate administration.

\section{References}

Green, K.C. \& Margaretz, G. (1967) Long-term follow-up of multicentre trial of ethyl- $\alpha-p$-chlorphenoxyisobutyrate (Clofibrate, 'Atromid'-S) and Clofibrate Plus Andro- sterone ('Atromid'). Progress in Biochemical Pharmacology, $2,378$.

Katsilambros, Braaten, J.B., Ferguson, D. \& Bradley, R.F. (1972) Muscular syndrome after clofibrate. New England Journal of Medicine, 286, 1110.

LANGER, T. \& LeVY, R.I. (1968) Acute Muscular Syndrome associated with administration of clofibrate. New England Journal of Medicine, 279, 856.

Smith, A.F., Macfie, W.G. \& Oliver, M.F. (1970) Clofibrate serum enzymes and muscle pains. British Medical Journal, ii, 86.

Vester, J.W., SABEH, G. \& DANovski, T.S. (1969) No muscle damage from clofibrate. New England Journal of Medicine, $280,110$.

\title{
Asymptomatic autoimmune liver disease in scleroderma
}

\author{
M. M. GuPTA \\ M.D.
}

\author{
T. W. WARNES \\ M.R.C.P.
}

\author{
L. WATSON \\ F.R.A.C.P. \\ Metabolic Ward, University College Hospital, Gower Street, London
}

\begin{abstract}
Summary
A case is described of scleroderma with asymptomatic autoimmune liver disease. The patient presented with the features of CRST syndrome (calcinosis, Raynaud's phenomenon, sclerodactyly and telangiectasia) and a raised plasma alkaline phosphatase was found on routine investigation. It is suggested that this latter biochemical finding is likely to indicate associated autoimmune liver disease in patients with scleroderma.

\section{Introduction}

There have been sporadic reports dating back to 1934 of liver disease occurring in patients with scleroderma but the association occurs rarely. Thus D'Angelo et al. (1969) found more instances of cirrhosis in fifty-eight control patients than in fiftyeight patients with systemic scleroderma, while Bartholomew et al. (1964) found only eight examples of chronic liver disease in 727 cases of scleroderma and concluded that there was no relationship between the two diseases. In 1958, Calvert et al. described two cases of scleroderma with portal hypertension who bled from oesophageal varices; in the first case, liver biopsy was not performed and in the

\footnotetext{
Correspondence: Dr T. W. Warnes, Metabolic Ward,
} University College Hospital, Gower Street, London WC1 6AU.
\end{abstract}

second it showed only patchy fibrotic changes. In 1970, Reynolds et al. and Murray-Lyon et al. independently described the association of primary biliary cirrhosis with scleroderma. All the eight patients described by these workers had evidence of florid liver disease. In this paper we describe a case of CRST syndrome (calcinosis, Raynaud's phenomenon, sclerodactyly and telangiectasia) who had neither symptoms nor signs of liver disease. Elevation of plasma alkaline phosphatase led to further investigations. On fractionation, the isoenzyme was shown to be of hepatic origin whilst the presence of antimitochondrial, antinuclear and smooth muscle antibodies in the serum suggested an associated autoimmune liver disease, which was confirmed by the histological findings on liver biopsy. We shall discuss this in relation to the recent observations of Fox, Scheuer and Sherlock (1973) that primary biliary cirrhosis may now be diagnosed when asymptomatic.

\section{Case report}

In 1960, a 41-year-old woman developed sclerodermatous changes in the fingers of the left hand with localized areas of subcutaneous calcification. Similar changes then appeared in the right hand and during the next 4 years calcinosis also developed over the left wrist. She developed Raynaud's phenomenon in 